Review

\title{
Immunotherapeutic Intervention against Sarcomas
}

\section{Paolo Pedrazzoli1, $1 \bowtie$, Simona Secondino ${ }^{1}$, Vittorio Perfetti ${ }^{1}$, Patrizia Comoli2 $^{2}$, Daniela Montagna ${ }^{3}$}

1. SC Oncologia, Fondazione IRCCS Policlinico S. Matteo, Pavia, Italy

2. Onco-ematologia Pediatrica, Fondazione IRCCS Policlinico S. Matteo, Pavia, Italy

3. Dipartimento di Scienze Pediatriche, Università di Pavia, Pavia, Italy, Fondazione IRCCS Policlinico San Matteo

4. Gruppo Italiano Trapianto di Midollo, Cellule Staminali Emopoietiche e Terapia Cellulare (GITMO)

$\triangle$ Corresponding author: Paolo Pedrazzoli, MD. SC Oncologia Fondazione IRCCS Policlinico S. Matteo, Piazzale Golgi, 19 27100 Pavia, Italy. p.pedrazzoli@smatteo.pv.it

(c) Ivyspring International Publisher. This is an open-access article distributed under the terms of the Creative Commons License (http://creativecommons.org/ licenses/by-nc-nd/3.0/). Reproduction is permitted for personal, noncommercial use, provided that the article is in whole, unmodified, and properly cited.

Received: 2011.05.02; Accepted: 2011.06.03; Published: 2011.06.13

\begin{abstract}
Advances in systemic therapy for sarcoma have produced, over the last two decades, relatively short-term benefits for the majority of patient. Among the novel biologic therapeutics that will likely increase our ability to cure human cancer in the years to come, immunotherapy is one of the most promising approaches. While past attempts to use immunotherapy have failed to dramatically shift the paradigm of care for the treatment of patients with sarcoma, major advances in basic and translational research have resulted, in more recent years, in clinical trial activity that is now beginning to generate promising results. However, to move from "proof of principle" to large scale clinical applicability, we need well-designed, multi-institutional clinical trials, along with continuous laboratory research to explore further the immunological characteristics of individual sarcoma subtypes and the consequent tailoring of therapy.
\end{abstract}

Key words: Immunotherapy, sarcoma

\section{Introduction}

Sarcomas constitute an extremely heterogeneous group of diseases, both in terms of histology and of biological and clinical behaviour [1]. Progress in the systemic treatment of sarcoma has been frustratingly slow. Prognosis of patients with metastatic or recurrent disease is poor and most of them will die from tumor progression. In such patients, with significant differences depending on histology subtype and age at disease onset, the overall median survival is around one year and about $10 \%$ of cases are alive at 5 years. Treatment of patients failing conventional treatments is mainly palliative as so far novel therapeutic approaches have not had a significant impact, with the exception of GIST, on the prognosis of these patients. This is in contrast with major advances in the understanding of the biology of this group of diseases.
Immunotherapy has long been discussed as a promising method for the treatment of patients with solid tumors but thus far its exact role in sarcoma remains to be defined. Previous reports have suggested that immune-based treatments may be effective in sarcoma, but such approaches have not yet become part of standard clinical practice. We now know that some promising targets for immunotherapy including cancer testis antigens are frequently expressed in certain sarcoma subtypes. [2,3]. Here we review prior trials of immunotherapy including nonspecific immunomodulators, vaccines, and adoptive T-cell therapy.

\section{Nonspecific Immunomodulation}

Nonspecific immunomodulation refers to ap- 
proaches of therapy aimed to induce antitumor immunity without exposing the patient to a target molecule.

Six sarcoma patients were included in one early high-dose interleukin 2 (IL-2) trial used in combination with limphokine-activated killer (LAK) cells [4]. None of the patients responded. More recently, high-dose IL-2 was given in a pediatric population including 4 patients with osteosarcoma and 2 patients with Ewing's sarcoma [5]. Two osteosarcoma patients had complete responses (CR) that were durable, which represents an encouraging finding that warrants more investigation focused on this sarcoma subtype.

Muramyl tripeptide phosphatidylethanolamine (MTP) is a synthetic analogue of a bacterial cell wall that has been studied clinically as a nonspecific immune modulator (Bacillus Calmette-Guerin). Based on early studies of a potential benefit of liposomal MTP in sarcoma [6,7], the Children's Oncology Group's Intergroup-0133 conducted a randomized trial in patients with newly diagnosed osteosarcoma. The study showed that ifosfamide added to the benefit seen with cisplatin and doxorubicin in the adjuvant setting, but only when the ifosfamide was given with liposomal MTP [8]. A subsequent report suggested that improvements in outcomes may also be seen in patients with metastatic disease although this analysis was not powered to demonstrate a statistically significant benefit in either event-free or overall survival [9]. To date, liposomal MTP has not secured FDA approval but is available at a number of centers for compassionate use.

Since the seventies interferon (IFN) has been employed in several sarcoma subtypes, particularly osteosarcoma, with contrasting results. Published studies (10-15, summarized in table 1$)$ do not allow to draw conclusion on the potential benefit of IFN in patients with sarcoma. In patients with localized osteosarcoma, who have had a good histological response to neoadjuvant chemotherapy, the European and American Osteosarcoma Study Group trial is conducting a randomized trial (EURAMOS 1) of postoperative systemic therapy consisting of methotrexate, doxorubicin, and cisplatin with or without pegylated IFN $a-2 b$. The pegylated preparation of IFN $a$ has an extended half-life and consequently can be administered less frequently with higher dose delivery. The results of this study will help to define the role of IFN in the adjuvant treatment of osteosarcoma.

\section{Vaccine Trials}

Vaccines expose patients to tumor antigens in order to evoke an antitumor immune response usually in the presence of adjuvant and occasionally in combination with immunomodulation $[3,16]$. In sarcoma patients, a number of small trials have been conducted using a variety of different vaccines, some with targeted well-defined antigens, others have targeted tumor lysate (summarized in table 2). In one trial [17], patients received an intradermal injection of irradiated autologous tumor cells along with either IFN gamma or GM-CSF as an adjuvant. Median survival was doubled among patients who were delayed-type hypersensitivity (DTH) skin test responders compared to those who were DTH nonresponders, but no measurable responses were reported. Among 10 pediatric patients treated with the same vaccination approach, one patient with fibrosarcoma had a partial response to the treatment which included the CR of several sizable pulmonary metastases [18].

Table 1: Reports of nonspecific immunomodulation with interferon (IFN) in sarcoma

\begin{tabular}{|c|c|c|c|c|}
\hline Treatment & \# pts/Histology & Clinical setting & Outcome & Reference \\
\hline Leukocyte IFN & 3 / osteosarcoma & Metastatic disease & $2 / 3$ partial responses & Ito, 1980 [10] \\
\hline r-IFN alfa-2a & 20 / bone sarcomas & Advanced disease & $\begin{array}{l}3 / 20 \text { short-lasting partial re- } \\
\text { sponses }\end{array}$ & Edmonson,1987 [11] \\
\hline IFN beta & 158 / osteogenic sarcoma & Adjuvant & $74 \% 2.5$ year disease free & Winkler, 1984 [12] \\
\hline r-IFN alfa- $2 b$ & 1 / clear cell sarcoma & Metastatic disease & CR lasting $17 \mathrm{mo}$ & Steger, 1991 [13] \\
\hline Leukocyte IFN alfa & 19 /osteosarcoma & Adjuvant & 12/195-year disease free & Strander, 1995 [14] \\
\hline r-IFN alfa & 178 / osteosarcoma & Adjuvant & $\begin{array}{l}39 \% 10 \text { year recurrence-free sur- } \\
\text { vival }\end{array}$ & Muller, 2005 [15] \\
\hline
\end{tabular}


Table 2: Reports of vaccine-based studies in sarcoma

\begin{tabular}{|c|c|c|c|}
\hline Vaccine & \# pts/Histology/clinical setting & Outcome & Reference \\
\hline Irradiated autologous tumor cells & $\begin{array}{l}\text { 16/variuos pediatric / } \\
\text { advanced disease }\end{array}$ & $\begin{array}{l}\text { Improved survival in skin test responders } \\
\text { (16.6 vs } 8.2 \text { mo). No tumor response }\end{array}$ & Dillmann, 2004 [17] \\
\hline $\begin{array}{l}\text { Dendritic cells pulsed with Tumor } \\
\text { lysate }\end{array}$ & $\begin{array}{l}\text { 10/various pediatric/ } \\
\text { advanced disease }\end{array}$ & One measurable response & Geiger, 2001 [18] \\
\hline $\begin{array}{l}\text { DC pulsed with tumor-specific pep- } \\
\text { tides }\end{array}$ & $\begin{array}{l}\text { 16/Ewing-rhabdo/ } \\
\text { Advanced, bulky }\end{array}$ & $\begin{array}{l}\text { One mixed response } \\
\text { Three stable disease }\end{array}$ & Dagher, 2002 [20] \\
\hline $\begin{array}{l}\text { DC pulsed with tumor lysate }(\#=3) \\
\text { SYT-SSX2 or EWS-FLI-1 peptides } \\
(\#=2)\end{array}$ & $\begin{array}{l}\text { 5/ various / } \\
\text { (residual tumor post auto TX) }\end{array}$ & $\begin{array}{l}\text { One complete response } 77 \mathrm{mo}+\text { (Ewing) } \\
\text { Two stable disease }\end{array}$ & Suminoe, 2009 [21] \\
\hline 105AD7 (against CD55) & $\begin{array}{l}\text { 28/osteosarcoma/ advanced, } \\
\text { post conventional chemother- } \\
\text { apy }\end{array}$ & $\begin{array}{l}\text { T cell response in vivo }(13 / 28) ; 1 \\
\text { long-lasting response }\end{array}$ & $\begin{array}{l}\text { Pritchard -Jones, } \\
2005[23]\end{array}$ \\
\hline
\end{tabular}

The largest dendritic cell vaccine trial to date enrolled 52 patients with $t(2 ; 13)$ or $t(11 ; 22)$ translocation positive, recurrent, or metastatic Ewing's sarcoma family of tumors or alveolar rhabdomyosarcoma [19]. All patients underwent prechemotherapy cell harvest via apheresis for potential receipt of immunotherapy. Following completion of standard multimodal therapy, 30 patients ultimately underwent immunotherapy with dendritic cells pulsed with peptides derived from tumor-specific translocation breakpoints and E7, a peptide known to bind HLA-A2. Toxicity was minimal. Intention-to-treat analysis suggested a longer overall survival for patients who received immunotherapy compared to all patients apheresed. While the results provided by this study are intriguing, a firm conclusion of the efficacy of this approach can only be drawn from a prospective randomized trial.

Other series of vaccine-based treatment including a limited number of patients have been reported [20-25], none providing clear evidence of a potential benefit of this approach in sarcoma patients.

There is an on-going randomized placebo controlled multicenter Phase II trial of a trivalent peptide vaccine to the gangliosides GD2, GD3, and GM2 in patients with advanced stage sarcoma rendered disease free by surgical resection. These gangliosides, thought to play a role in cell adhesion and cell-cell interactions, may be expressed in some sarcomas [26-28] and one report suggests that soft tissue sarcoma patients develop an antibody response to GD2 more frequently than healthy subjects [29]. On the other hand, it is worth noting that a randomized trial of gangliosidein in melanoma failed to demonstrate improvement in survival [30].

\section{Adoptive T-Cell Therapy (ATCT)}

ATCT involves the expansion either ex vivo (for later reinfusion) or in vivo, of immune effector cells capable of tumor killing. This may be nonspecific, as in the case of allogeneic hematopoietic stem cell transplantation (HSCT), or cytokine-induced killer (CIK), or may use tumor/antigen-specific ex vivo cultures or genetically engineered cells to have tumor-directed specificity.

\section{Nonspecific ATCT}

\section{Allogeneic Stem Cell Transplantation}

Evidence of an immune-mediated effect against sarcoma in experimental animal models of allogeneic HSCT has been reported since the $80^{\prime}$ [31,32]. Based on these preclinical results single case reports and small series of patients with sarcoma treated with allogeneic HSCT from HLA-matched sibling donors have been reported with contrasting results [33,34]. A retrospective analysis of adult patients with soft tissue sarcoma registered at the EBMT database [35] was not able to draw firm conclusions about a possible role of allogeneic transplantation in advanced STS, mainly because of the heterogeneity of the patient population.

Recently, Thiel et al [36] retrospectively analyzed data of 87 Ewing sarcoma patients from various registries treated with allogeneic HSCT and evaluated the outcome regarding the use of reduced-intensity conditioning (RIC) and high-intensity conditioning (HIC) regimens as well as human leukocyte antigen (HLA)-matched and HLA-mismatched grafts. There was no improvement of survival with RIC compared with HIC due to increased relapse incidence after RIC despite less transplant-related mortality (TRM) incidence. HLA mismatch was not generally associated with a greater antitumor effect. These results suggest general absence of a clinically relevant Graft-versus Sarcoma effect.

Allogeneic HSCT can be viewed, in perspective, as a platform for additional approaches of adoptive 
immunotherapy [37]. The donor immune system can in fact permit the repeated infusion of alloimmune lymphocytes, tumor-specific T cells or NK/CIK cells from the donor without risking their rejection.

\section{Cytokine-Induced Immune Effector Cells}

LAK cells are cytotoxic effector lymphocytes whose cytolytic activities are not restricted by major histocompatibility complex (MHC) and have the ability to kill fresh tumor cells and NK-resistant tumor cell lines [38]. LAK cells are generated from blood lymphocytes following expansion in the presence of IL-2 for a 5-day culture period. LAK cells demonstrated potent in vitro cytotoxicity against susceptible tumor cells and led to the regression of established tumors in animal models [39-41]. In clinical studies, LAK cells had shown modest efficacy in solid tumors such as renal cell carcinoma, melanoma and hepatocellular carconoma $[42,43]$ and no data are available in the setting of sarcoma.

Closely related to LAK cells, CIK cells are polyclonal $\mathrm{T}$ effector cells generated in vitro by incubation of peripheral blood lymphocytes with anti-CD3 monoclonal antibody, IL-2, IL-1 alpha, and interferon-gamma [44]. This unique subset of non-MHC-restricted CD3+CD56+ T cells was referred to as NK-like T cells since, similar to the NK cells, they do not require prior specific sensitization to induce the recognition of target cells. CIK cells have a high rate of proliferation and demonstrate a potent cytolytic activity in vitro against a variety of tumor targets, including sarcomas [45.46]. However, data on the efficacy of CIK cells in vivo are limited [47].

CIK cells show only limited graft-versus-host effects in various mouse models [48] which suggest their potential use as adoptive immunotherapy following allogeneic transplantation $[49,50]$ i.e as an effective alternative to classic donor lymphocyte infusion [51].

\section{Targeted ATCT}

A strategy that has proven effective in increasing the efficacy of anticancer cell therapy protocols is the ex vivo identification of autologous or allogeneic lymphocytes with antitumour activity, which are then administered to cancer patients. A number of different approaches have been so far employed to obtain tumor-specific T cells, such as: ex vivo selection TIL based on their capacity to recognize autologous tumor cells, repeated in vitro stimulation with tumor-associated antigens (TAA)/whole tumor cells, or, more recently, genetic modification of T-cells using $\mathrm{T}$-cell receptors encoding retroviruses, that can con- vert normal lymphocytes into cells with specific anti-cancer activity.

\section{Tumor-Infiltrating Lymphocytes}

TIL therapy can be considered a targeted T cell therapy as they are ex vivo selected for their capacity to recognize autologous tumor cells. Transfusion of TIL has emerged as the most effective treatment for patients with metastatic melanoma, a decisive improvement in their efficacy coming with the introduction of an immunodepleting preparative regimen given before the adoptive transfer, which resulted in the clonal repopulation of patients with anti-tumour $\mathrm{T}$ cells [52]. Though some early work did seem to demonstrate that TIL can be grown in culture from patients with sarcoma $[53,54]$, with variable yield, no clinical data are available. We believe that this may represent an area of future developement.

\section{T-Cell Lines Specific for TAA}

Over the last decade, progress in the field of biotechnology has allowed for the characterization of tumor cells, with identification of tumor-specific or tumor associated antigens. However, the number of TAA identified so far is relatively limited if compared to the plethora of molecules present on tumor cells that may contribute to stimulate a protective immune response. To overcome this problem, during the past few years, the use of dendritic cells pulsed with whole tumor cell preparations, to cross-prime cytotoxic T-lymphocytes (CTLs) has been investigated [55-57]. Montagna et al. demonstrated the feasibility of obtaining large quantities of autologous anti-tumor specific CTLs generated by stimulation of patients' peripheral blood mononuclear cells with dendritic cells pulsed with apoptotic tumor cells [58]. In a pilot study [59], the same authors have shown that anti-tumor CTLs can be administered safely in patients with advanced solid malignancies, including sarcoma, and can improve the immunological status of recipients against tumor. The clinical efficacy of such immunotherapeutic approach will be investigated further in a phase II study.

Very recently, It has been shown that cancer stem-like cells/ cancer-initiating cells of bone malignant fibrous histiocytoma are recognized by autologous CTLs in the tumor microenvironment and peripheral circulating lymphocytes [60] which support the hypothesis that CTL-based immunotherapy could target cancer stem cells of bone sarcoma.

\section{ATCT with T-Cells Specific for Viral Antigens}

A rare example of solid cancer setting in which tumor-specific $\mathrm{T}$ cells have been employed with suc- 
cess is virus-related tumors. In particular, independent phase I-II studies demonstrated that clinical and immunological responses can be obtained in patients with radiotherapy- and chemotherapy-resistant, EBV-related nasopharingeal carcinoma by administration of EBV-specific autologous polyclonal CTL therapy [61-64]. No clinical data are yet available in the setting of virus-related sarcomas and this may well be an area of future development in selected patients [65-66].

\section{T-Cells Modified to Express Chimeric Receptors}

A strategy to broaden the reactivity against shared cancer-associated antigens present on multiple tumour types consists in grafting specificities for antigens expressed on tumour cells through genetic manipulation [67]. Investigators have developed artificial T-cell receptors, also referred to as chimeric antigen receptors, isolated from high avidity $\mathrm{T}$ cells that recognize cancer antigens, and retroviral or lentiviral vectors have been used to redirect lymphocyte specificity to these cancer antigens. Clinical studies in B-cell haematological malignancies [68] and subsequently in solid tumors [69-72] demonstrated that normal human lymphocytes genetically engineered to express a TAA, can mediate cancer regression in vivo. Very recently, Robbins et al [73] reported on the ability of adoptively transferred autologous $\mathrm{T}$ cells transduced with a T-cell receptor (TCR) directed against the cancer testis antigen NY-ESO-1 to mediate tumor response in metastatic synovial cell sarcoma. Objective clinical responses were observed in four of six patients with synovial cell sarcoma including a near CR lasting 18 months. This represents the first demonstration of the successful treatment of a nonmelanoma tumor using TCR-transduced T cells. The NY-ESO-1 antigen is expressed in $80 \%$ of synovial sarcoma but also in $15 \%$ to $50 \%$ of highly prevalent tumors that include breast, lung, prostate, and ovarian cancer [74,75]. Therefore, effective therapies that target NY-ESO-1 could potentially be applied to the large population of cancer patients.

\section{Conclusions}

Over the years immunotherapeutic approaches have shown signals of great potential in selected patients with sarcoma. As an example, the dramatic responses to T-cell therapy recently demonstrated in synovial cell sarcoma. Studies like this just scratch the surface of what might be feasible for patients with sarcomas in the future, since as many as $25 \%$ of sarcomas have reproducible genetic changes.

To move from "proof of principle" to large scale clinical applicability we need well-designed, multi- institutional clinical trials, along with continuous laboratory research to explore further the immunological characteristics of individual sarcoma subtypes and the consequent tailoring of therapy.

While past attempts to use immunotherapy have failed to dramatically shift the paradigm of care for the treatment of patients with sarcoma, a great opportunity now exists to increase the therapeutic options available in this challenging group of diseases.

\section{Conflict of Interest}

The authors have declared that no conflict of interest exists.

\section{References}

1. DeVita VT, Lawrence TS, Rosenberg SA. Cancer: Principles and Practice of Oncology - 8th edition. US: Lippincott Williams \& Wilkins, 2008.

2. Maki RG. Soft tissue sarcoma as a model disease to examine cancer immunotherapy. Current Opinion in Oncology. 2001;13:270-4.

3. Pollack SM., Loggers ET, Rodler ET, Yee C, Jones RL. Immune-based therapies for sarcoma. Sarcoma. 2011;2011:438940.

4. Rosenberg SA, Lotze MT, Yang JC, et al. Experience with the use of high-dose interleukin-2 in the treatment of 652 cancer patients. Annals of Surgery. 1989;210:474-85.

5. Schwinger W, Klass V, Benesch M, et al. Feasibility of high-dose interleukin-2 in heavily pretreated pediatric cancer patients. Annals of Oncology. 2005;16:1199-06.

6. Murray JL, Kleinerman ES, Cunningham JE, et al. Phase I trial of liposomal muramyl tripeptide phosphatidylethanolamine in cancer patients. Journal of Clinical Oncology. 1989;7:1915-25.

7. Kleinerman ES, Jia SF, Griffin J, Seibel NL, Benjamin RS, Jaffe N. Phase II study of liposomal muramyl tripeptide in osteosarcoma: the cytokine cascade and monocyte activation following administration. Journal of Clinical Oncology. 1992;10:1310-16.

8. Meyers PA, Schwartz CL, Krailo M, et al. Osteosarcoma: a randomized, prospective trial of the addition of ifosfamide and/or muramyl tripeptide to cisplatin, doxorubicin, and high-dose methotrexate. Journal of Clinical Oncology. 2005;23:2004-11.

9. Chou AJ, Kleinerman ES, Krailo MD, et al. Addition of muramyl tripeptide to chemotherapy for patients with newly diagnosed metastatic osteosarcoma: a report from the Children's Oncology Group. Cancer. 2009;115:5339-48.

10. Ito H, Murakami K, Yanagawa T. Effect of human leukocyte interferon on the metastatic lung tumor of osteosarcoma. Case reports. Cancer. 1980;46:1562-65.

11. Edmonson JH, Long HJ, Frytak S, Smithson WA, Itri LM. Phase II study of recombinant alfa-2a interferon in patients with advanced bone sarcomas. Cancer Treatment Reports. 1987;71:747-8.

12. Winkler K, Beron G, Kotz R. Neoadjuvant chemotherapy for osteogenic sarcoma: results of a cooperative German/Austrian study. Journal of Clinical Oncology. 1984;2:617-24.

13. Steger GG, Wrba F, Mader R, Schlappack O, Dittrich C, Rainer $\mathrm{H}$. Complete remission of metastasised clear cell sarcoma of tendons and aponeuroses. European Journal of Cancer. 1991;27:254-6.

14. Strander $\mathrm{H}$, Bauer $\mathrm{HC}$, Brosjo $\mathrm{O}$, et al. Long-term adjuvant interferon treatment of human osteosarcoma. A pilot study. Acta Oncologica. 1995;34:877-80. 
15. Müller CR, Smeland S, Bauer HCF, Sæter G, Strander H. Interferon- $\alpha$ as the only adjuvant treatment in high-grade osteosarcoma: long term results of the Karolinska Hospital series. Acta Oncologica. 2005;44:475-80.

16. Kantoff PW, Higano CS, Shore ND, et al. Sipuleucel-T immunotherapy for castration-resistant prostate cancer. New England Journal of Medicine. 2010;363:411-22

17. Dillman R, Barth N, Selvan S, et al. Phase I/II trial of autologous tumor cell line-derived vaccines for recurrent or metastatic sarcomas. Cancer Biotherapy and Radiopharmaceuticals. 2004;19:581-88.

18. Geiger JD, Hutchinson RJ, Hohenkirk LF, et al. Vaccination of pediatric solid tumor patients with tumor lysate-pulsed dendritic cells can expand specific T cells and mediate tumor regression. Cancer Research. 2001;61:8513-19.

19. Mackall CL, Rhee EH, Read EJ, et al. A pilot study of consolidative immunotherapy in patients with high-risk pediatric sarcomas. Clinical Cancer Research. 2008;14:4850-8.

20. Dagher R, Long LM, Read EJ, et al. Pilot trial of tumor-specific peptide vaccination and continuous infusion interleukin-2 in patients with recurrent Ewing sarcoma and alveolar rhabdomyosarcoma: an inter-institute NIH study. Medical and Pediatric Oncology. 2002;38:158-64.

21. Suminoe A, Matsuzaki A, Hattori H, Koga Y, Hara T. Immunotherapy with autologous dendritic cells and tumor antigens for children with refractory malignant solid tumors. Pediatric Transplantation. 2009;13:746-53.

22. Ullenhag GJ, Spendlove I, Watson NFS, Kallmeyer C, Pritchard-Jones K, Durrant LG. T-cell responses in osteosarcoma patients vaccinated with an anti-idiotypic antibody, 105AD7, mimicking CD55. Clinical Immunology. 2008;128:148-54

23. Pritchard-Jones K, Spendlove I, Wilton C, et al. Immune responses to the 105AD7 human anti-idiotypic vaccine after intensive chemotherapy, for osteosarcoma. British Journal of Cancer. 2005;92:1358-65.

24. Kawaguchi S, Wada T, Ida K, et al. Phase I vaccination trial of SYT-SSX junction peptide in patients with disseminated synovial sarcoma. Journal of Translational Medicine. 2005;3:1.

25. Ida K, Kawaguchi S, Sato Y, et al. Crisscross CTL induction by SYT-SSX junction peptide and its HLA-A*2402 anchor substitute. Journal of Immunology. 2004;173:1436-43.

26. Zhang S, Cordon-Cardo C, Zhang HS, et al. Selection of tumor antigens as targets for immune attack using immunohistochemistry: I. Focus on gangliosides. International Journal of Cancer. 1997;73:42-9.

27. Heiner JP, Miraldi F, Kallick S, et al. Localization of G(D2)-specific monoclonal antibody 3F8 in human osteosarcoma. Cancer Research. 1987;47:5377-81.

28. Lipinski M, Braham K, Philip I. Neuroectoderm-associated antigens on Ewing's sarcoma cell lines. Cancer Research. 1987;47:183-7.

29. Perez CA, Ravindranath MH, Soh D, Gonzales A, Ye W, Morton DL. Serum anti-ganglioside IgM antibodies in soft tissue sarcoma: clinical prognostic implications. Cancer Journal. 2002;8:384-94.

30. Kirkwood JM, Ibrahim JG, Sosman JA, et al. High-dose interferon alfa- $2 \mathrm{~b}$ significantly prolongs relapse-free and overall survival compared with the GM2-KLH/QS-21 vaccine in patients with resected stage IIB-III melanoma: results of intergroup trial E1694/S9512/C509801. J Clini Oncol. 2001;19:2370-80.

31. Moscovitch, Slavin S. Anti-tumor effects of allogeneic bone marrow transplantation in (NZB X NZW) F1 hybrids with spontaneous lymphosarcoma. J Immunol 1984;132:997-1000.

32. Deichman GI, Kashkina LM, Kluchareva TE, Vendrov EL, Matveeva VA. Inhibition of experimental and spontaneous lung metastases of highly metastatic Syrian hamster sarcoma cells by non-activated bone marrow and peritoneal exudate cells. Int J Cancer 1983;3:609-15.

33. Castagna L, Sarina B, Todisco E, Mazza R, Santoro A. Lack of activity of allogeneic stem cell transplantation with reduced-intensity conditioning regimens in advanced sarcomas. Bone Marrow Transplant 2005;35:421-2.

34. Misawa A, Hosoi H, Tsuchiya K, Iehara T, Sawada T, Sugimoto T. Regression of refractory rhabdomyosarcoma after allogeneic stem-cell transplantation. Pediatr Hematol Oncol 2003;20:151-5.

35. Secondino S, Carrabba MG, Pedrazzoli P, et al. Reduced intensity stem cell transplantation for advanced soft tissue sarcomas in adults: a retrospective analysis of the European Group for Blood and Marrow Transplantation. Haematologica. 2007; $92: 418-20$

36. Thiel U, Wawer A, Wolf $P$, et al. No improvement of survival with reduced- versus high-intensity conditioning for allogeneic stem cell transplants in Ewing tumor patients. Ann Oncol. 2011; Epub ahead of print.

37. Demirer T, Barkholt L, Blaise D, et al., on behalf of the EBMT Solid Tumors Working Party. Transplantation of allogeneic hematopoietic stem cells: an emerging treatment modality for solid tumors. Nature Clin Pract Oncol 2008;5:256-67.

38. Grimm EA, Mazumder A, Zhang HZ, Rosenberg SA. Lymphokine-activated killer cell phenomenon. Lysis of natural killer-resistant fresh solid tumor cells by interleukin 2-activated autologous human peripheral blood lymphocytes. J Exp Med 1982;155:1823-41.

39. Mazumder A, Rosenberg SA. Successful immunotherapy of natural killer-resistant established pulmonary melanoma metastases by the intravenous adoptive transfer of syngeneic lymphocytes activated in vitro by interleukin 2. J Exp Med 1984;159:495-507.

40. Lafreniere R, Rosenberg SA. Successful immunotherapy of murine experimental hepatic metastases with lymphokine-activated killer cells and recombinant interleukin 2. Cancer Res 1985;45:3735-41.

41. Berezhnaya NM, Vinnichuk YD, Belova OB. The use of doxorubicine at low doses for elevation of LAK-activity toward explants and cells of MC-rhabdomyosarcoma and B16 melanoma resistant to doxorubicin. Exp Oncol. 2008;30:52-5.

42. Rosenberg SA, Lotze MT, Muul LM. A progress report on the treatment of 157 patients with advanced cancer using lymphokine-activated killer cells and interleukin-2 or high-dose interleukin-2 alone. New Engl J Med 1987;316:889-97.

43. Takayama T, Sekine T, Makuuchi M, Yamasaki S, Kosuge T, Yamamoto J et al. Adoptive immunotherapy to lower postsurgical recurrence rates of hepatocellular carcinoma: a randomised trial. Lancet 2000;356:802-7.

44. Linn YC, Hui KM. Cytokine-induced NK-like T cells: from bench to bedside. J Biomed Biotechnol. 2010;2010:435745.

45. Hongeng S, Petvises S, Worapongpaiboon S, Rerkamnuaychoke B, Pakakasama S, Jootar S. Generation of CD3+ CD56+ cytokine-induced killer cells and their in vitro cytotoxicity against pediatric cancer cells. Int J Hematol. 2003;77:175-9

46. Wang Y, Dai H, Li H, Lv H, Wang T, Fu X, et al. Growth of Human Colorectal Cancer SW1116 Cells Is Inhibited by Cytokine-Induced Killer Cells. Clin Dev Immunol 2011; epub.

47. Hontscha C, Borck Y, Zhou H, Messmer D, Schmidt-Wolf IGH. Clinical trials on CIK cells: first report of the international registry on CIK cells (IRCC). J Cancer Res Clin Oncol 2011;137:305-10.

48. Baker J, Verneris MR, Ito M, Shizuru JA, Negrin RS. Expansion of cytolytic CD8(+) natural killer T cells with limited capacity for graft-versus-host disease induction due to interferon gamma production. Blood 2001;97:2923-31. 
49. Kuçi S, Rettinger E, Voß B, Weber G, Stais M, Kreyenberg H, et al. Efficient lysis of rhabdomyosarcoma cells by cytokine-induced killer cells: implications for adoptive immunotherapy after allogeneic stem cell transplantation. Haematologica 2010;95:1579-86.

50. Introna M, Pievani A, Borleri G, Capelli C, Algarotti A, Micò C, et al. Feasibility and safety of adoptive immunotherapy with CIK cells after cord blood transplantation. Biol Blood Marrow Transplant 2010;16:1603-7.

51. Sangiolo D, Mesiano G, Carnevale-Schianca F, Piacibello W, Aglietta M, Cignetti A. Cytokine induced killer cells as adoptive immunotherapy strategy to augment graft versus tumor after hematopoietic cell transplantation. Expert Opin Biol Ther 2009;9:831-40.

52. Rosenberg SA, Dudley ME. Adoptive cell therapy for the treatment of patients with metastatic melanoma. Curr Opin Immunol 2009;21:233-40.

53. Topalian SL, Muul LM, Solomon D, Rosenberg SA. Expansion of human tumor infiltrating lymphocytes for use in immunotherapy trials. Journal of Immunological Methods. 1987;102:127-41.

54. Balch CM, Riley LB, Bae YJ, et al. Patterns of human tumor-infiltrating lymphocytes in 120 human cancers. Archives of Surgery. 1990;125:200-5.

55. Osman Y, Takahashi M, Zheng Z, Toba K, Liu A, Furukawa T, et al. Activation of autologous or HLA identical sibling cytotoxic $\mathrm{T}$ lymphocytes by blood derived dendritic cells pulsed with tumor cell extract. Oncol Rep 1999;6:1057-63.

56. Hoffmann TK, Meidenbauer N, Dworacki G, Kanaya H, Whiteside T. Generation of tumor-specific T lymphocytes by cross-priming with human dendritic cells ingesting apoptotic tumor cells. Cancer Res 2000;60:3542-9.

57. Kurokawa T, Oelke M, Mackensen A. Induction and clonal expansion of tumor specific cytotoxic lymphocytes from renal cell carcinoma patients after stimulation with autologous dendritic cells loaded with tumor cells. Int J Cancer 2001;91:749-756.

58. Montagna D, Schiavo R, Gibelli N, et al. Ex vivo generation and expansion of anti-tumor cytotoxic T-cell lines derived from patients or their HLA-identical sibling. Int J Cancer 2004;110:76-86.

59. Montagna D, Turin I, Schiavo R, et al. Feasibility and safety of adoptive immunotherapy with ex-vivo generated autologous, cytotoxic $\mathrm{T}$ lymphocytes in patients with solid tumor. Cytotherapy. 2011; in press.

60. Kano M, Tsukahara T, Emori M, et al. Autologous CTL response against cancer stem-like cells/ cancer-initiating cells of bone malignant fibrous histiocytoma. Cancer Sci. 2011; Epub ahead of print.

61. Straathof KC, Bollard CM, Popat U, Huls MH, Lopez T, Morriss $\mathrm{MC}$, et al. Treatment of nasopharyngeal carcinoma with Epstein-Barr virus-specific $\mathrm{T}$ lymphocytes. Blood 2005; 105:1898-904.

62. Comoli P, Pedrazzoli P, Maccario R, Basso S, Carminati O, Labirio $\mathrm{M}$, et al. Cell therapy of stage IV nasopharyngeal carcinoma with autologous EBV-targeted cytotoxic T-lymphocytes. J Clin Oncol 2005;23:8942-9

63. Louis CU, Straathof K, Bollard CM, Gerken C, Huls MH, Gresik $\mathrm{MV}$, et al. Enhancing the in vivo expansion of adoptively transferred EBV-specific CTL with lymphodepleting CD45 monoclonal antibodies in NPC patients. Blood 2009;113:2442-50.

64. Secondino S, Zecca M, Licitra L, et al. T-cell therapy for EBV-associated nasopharyngeal carcinoma: preparative lymphodepleting chemotherapy does not improve clinical results. Ann Oncol 2011; in press.

65. Okroj M, Tedeschi R, Mancuso R. Prevalence of antibodies against Kaposi's sarcoma associated herpes virus (KSHV) com- plement inhibitory protein $(\mathrm{KCP})$ in KSHV-related diseases and their correlation with clinical parameters. Vaccine. 2011;29:1129-34.

66. McClain KL, Leach CT, Jenson HB, et al. Association of Epstein-Barr virus with leiomyosarcomas in children with AIDS. N Engl J Med. 1995;332:12-8.

67. Sadelain M, Riviere I, Brentjens R. Targeting tumours with genetically enhanced T lymphocytes. Nature Reviews Cancer 2003;3:35-45.

68. Brentjens RJ, Latouche JB, Santos E, Marti F, Gong MC, Lyddane $C$, et al. Eradication of systemic B-cell tumors by genetically targeted human $\mathrm{T}$ lymphocytes co-stimulated by CD80 and interleukin-15. Nature Medicine 2003; 9: 279-86.

69. Kershaw MH, Westwood JA, Parker LL Wang G, Eshhar Z, Mavroukakis SA, et al. A phase I study on adoptive immunotherapy using gene modified T cells for ovarian cancer. Clinical Cancer Research 2006;12:6106-15.

70. Lamers CH, Langeveld SC, Groot-van Ruijven CM, Debets R, Sleijfer S, Gratama JW. Gene-modified T cells for adoptive immunotherapy of renal cell cancer maintain transgene-specific immune functions in vivo. Cancer Immunology Immunotherapy 2007;56:1875-83.

71. Pule MA, Savoldo B, Myers GD, et al. Virus-specific T cells engineered to coexpress tumor-specific receptors: persistence and antitumor activity in individuals with neuroblastoma. Nat Med 2008;14:1264-70.

72. Hunder NN, Wallen $\mathrm{H}$, Cao J, et al. Treatment of metastatic melanoma with autologous CD4+ T cells against NY-ESO-1. N Engl J Med 2008;358:2698-703.

73. Robbins PF, Morgan RA, Feldman SA, et al. Tumor regression in patients with metastatic synovial cell sarcoma and melanoma using genetically engineered lymphocytes reactive with NY-ESO-1. J Clin Oncol 2011; 29: 917-24.

74. Chen YT, Scanlan MJ, Sahin U, et al: A testicular antigen aberrantly expressed in human cancers detected by autologous antibody screening. Proc Natl Acad Sci U S A. 1997;94:1914-8.

75. Gure AO, Chua R, Williamson B, et al: Cancer testis genes are coordinately expressed and are markers of poor outcome in non-small cell lung cancer. Clin Cancer Res. 2005;11:8055-62. 